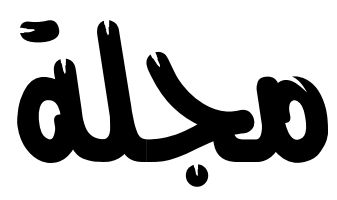

فُطاع أصول الينَ بالقاهرة

علمية - سنوينة - محكمة

العدد الرابع عشر

رلئيسن مجلنس الإكارة

أ . د /عبد الفناحعبد الغني العواسي لهي

عميذالكلية

$$
\text { المعلد الأول }
$$




$$
\begin{aligned}
& \text { هبلة قطاع أصول الدين } \\
& \text { بالقاهرة } \\
& \text { كلية أصول الدين بالقاهرة } \\
& \text { بدار الإيمان للطباعة } \\
& .1 .919019 r \\
& \text { بريد إلكتروني / } \\
& \text { selhosaryl1@yafroo.com } \\
& \text { بدار الكتب الصرية } \\
& \text { r. IA/ Iravo }
\end{aligned}
$$




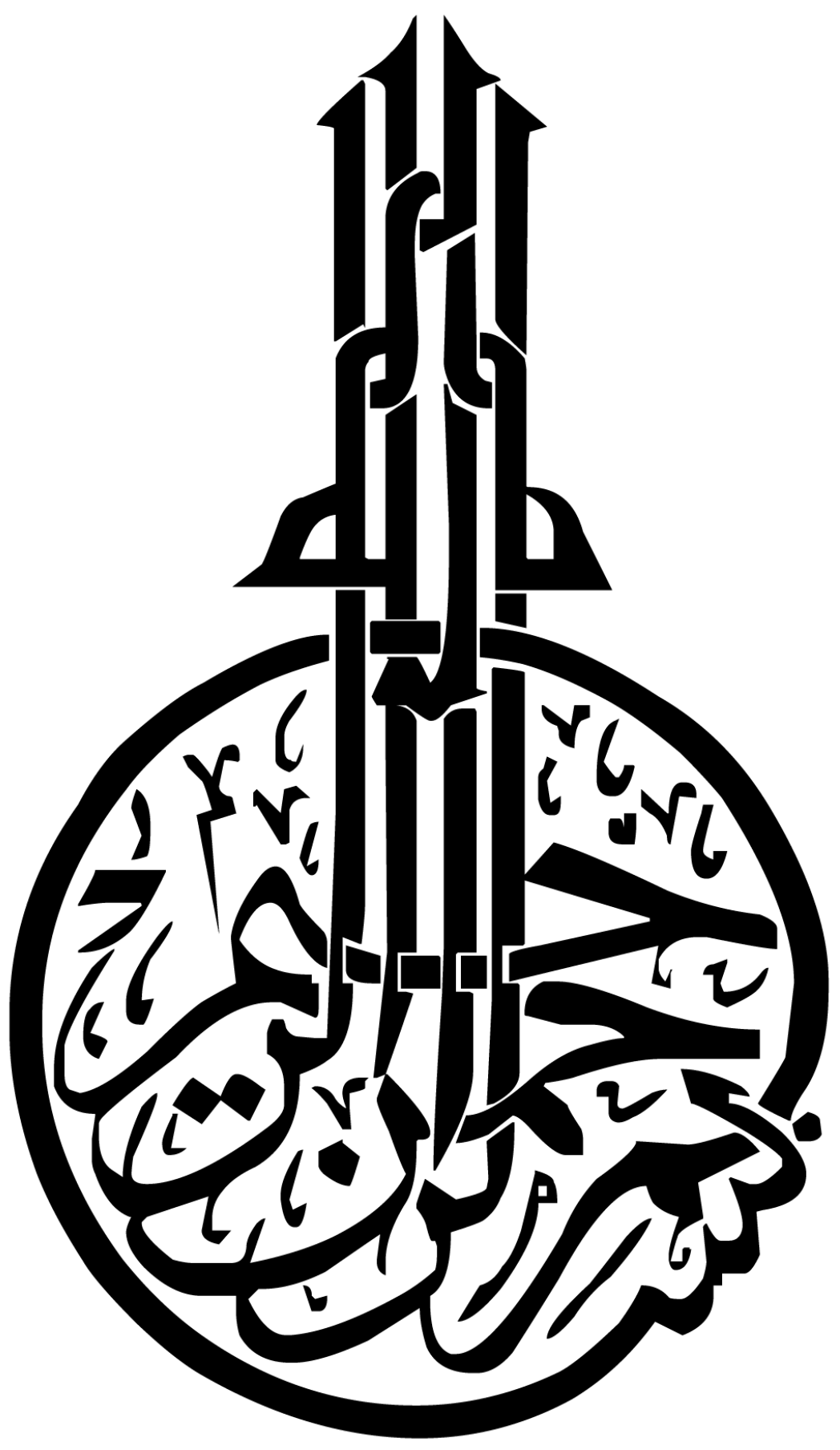





\section{ضوابط وقواعد النشر}

الأساتذة الأفاضل والعلماء الأجلاء والأخوة الزملاء يسعد إدارة الكلية

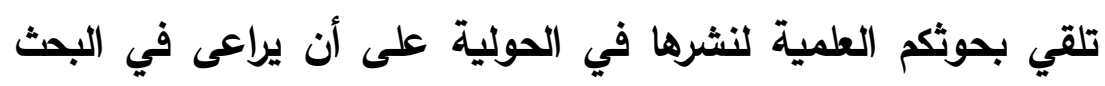
المقدم للنشر الضوابط والقواعد الآتية :

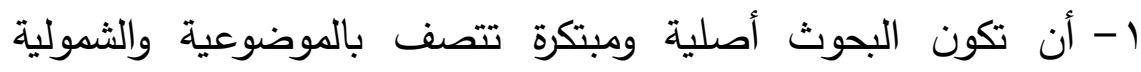
والعمق ، ولا تتعارض مع القيم الإسلامية ، وذلك بعد عرضها على البحلى محكمين حسب الأصول العلمية المتبعة .

r - ألا يكون البحث قد نشر من قبل أو قدم للنشر إلى جهة أخرى ، وألا

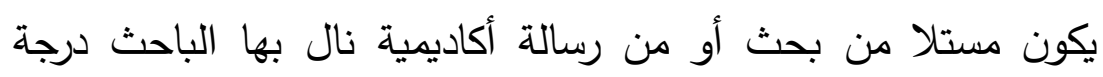

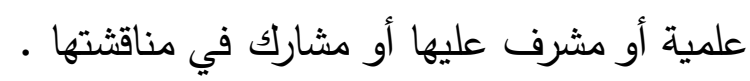
r - يراعى في البحوث المتضمنة نصوصا شرعية ضبط تلك النصوص، وذلك بتوثيق الآيات القرآنية ، وتخريج الأحاديث النبوية الثريفة في نصية

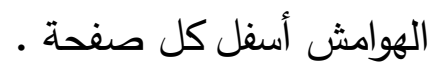
ع -ألا يتجاوز البحث (.0) صفحة شاملة الغلاف والفهارس ، مع مراعاة الضوابط الفنية الآتية :

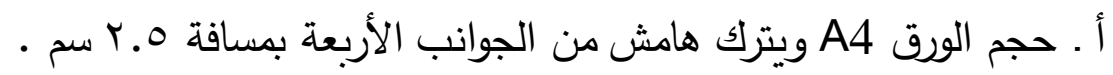

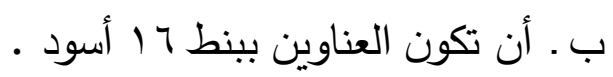

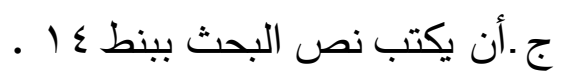

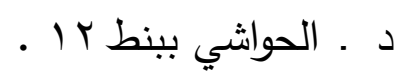

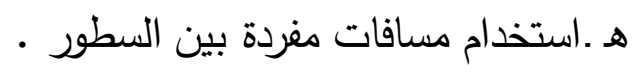
0 - يقدم البحث للجنة المختصة بالإثراف على طباعة الحولية بعد موافقة الوحدة العلمية والقسم الذي ينتسب إليه الباحث هذا لأعضاء هيئة 
التدريس بالكلية أما بحوث الأساتذة من الخارج فتقدم لهيئة التحرير مباشرة .

1 - ترقم الجداول والأشكال والنماذج المخطوطة والصور التوضيحية وغيرها

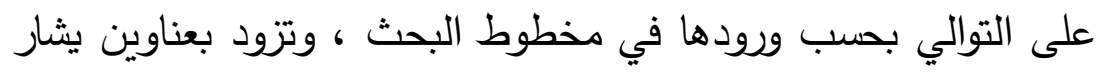
إلى كل منها بالتسلسل نفسه في متن المخطوط وتقدام بأوراق منفصلة .

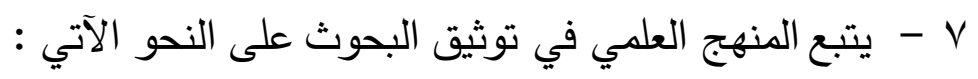

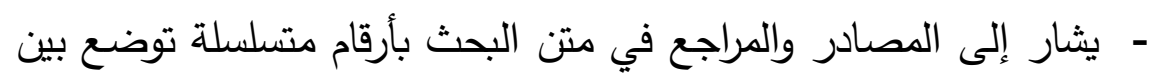
قوسين إلى الأعلى [هكذا:( (1) (Y)] وتبين بالتفصيل في أسفل كل صفحة على حدة.

- - يشار إلى الثروح والملحوظات في متن البحث بنجمة (هكذا:" ) أو أكثر .

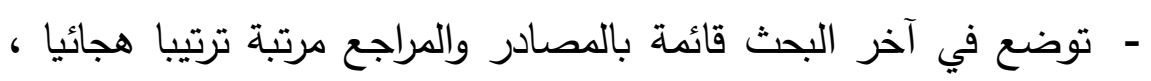
بحسب اسم الثهرة تتبعه معلومات الكتاب الأخرى ، يتصدرها القرآن الكريم إن كان من ضمنها ، على النحو التالي :

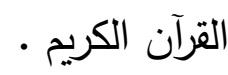

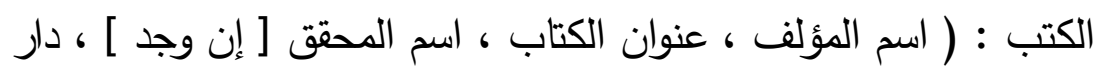

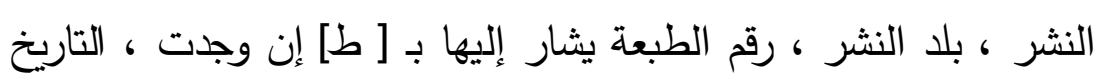

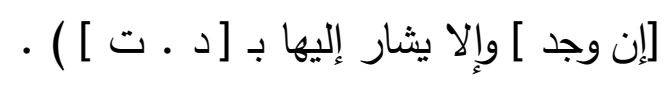

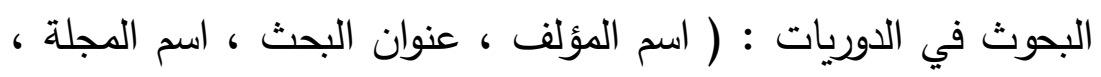

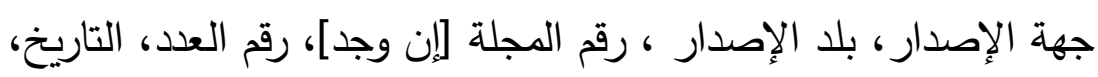
مكان البحث في المجلة ممثلا بالصفحات).

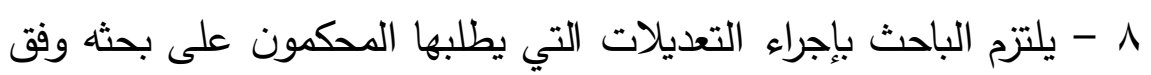

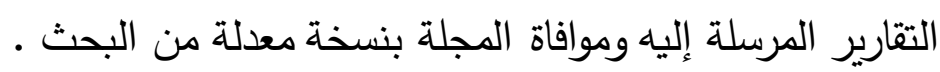


ميع العلم بأن : مأن

• ما ينشر في الحولية من آراء يعبر عن فكر أصحابها ، ولا يمثل رأي

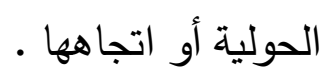

البحوث المرسلة إلى الحولية لا تعاد إلى أصحابها سواء نشرت أم لم

ت تنشر

• إعلام أصحاب البحوث الواردة بوصولها إلى لجنة الإشراف .

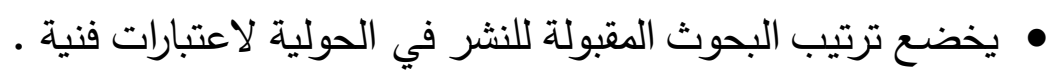

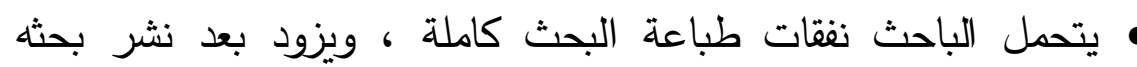

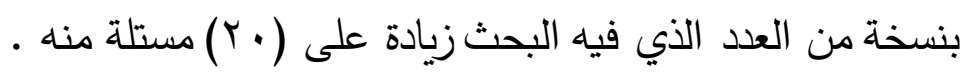



مباخلم إدارة

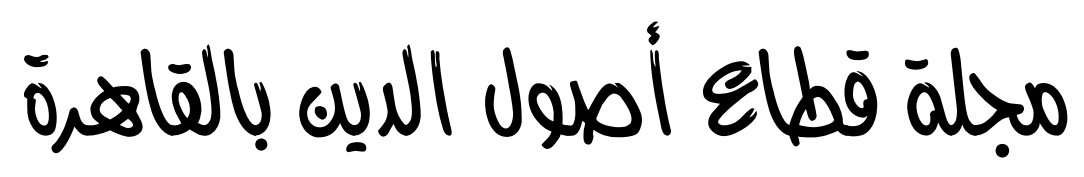

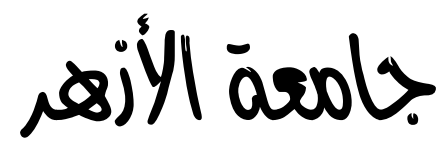

رئيس هجلس الإدارة

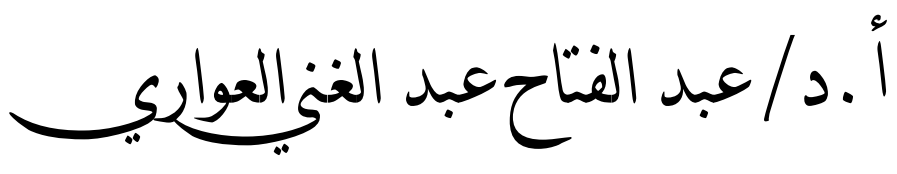

عميد كلية أصول الدين بالقاهرة 
أعضاء مجللن الإكارة :

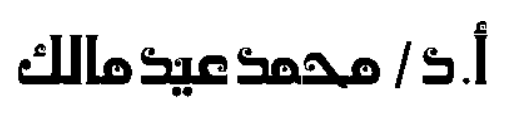

عميد كلية أصول الدين والدعوة بأسيوط

$$
\text { أ.ذ / أحمك علي علي عمينية }
$$

عميد كاية أصول الدين والدعوة بطنطا

أ. ذ / سعك محمك محمك شالبهي

عميد كلية أصول الدين والدعوة بالمنصورة

أ. ذ / اعتماك عبنكالصاكق عفينهيc

عميد كلية الدراسات الإسلاهية بنات - القاهرة

أ. ذ / سامي عبكالفنتالحهل

عميد كلية القرآن الكريم بطنطا

أ. ك / جمال فاروق جبريل

عميد كلية الدعوة الإسلاهية بالقاهرة

أ. ذ / طهه عبنكالخالق عبكالعزيزي

وكيل كلية أصول الدين بالقاهرة للدراسات العليا

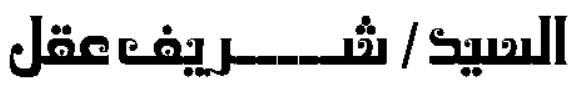

هدير عام مكتبة الكلية وسكرتير تهرير الملة 


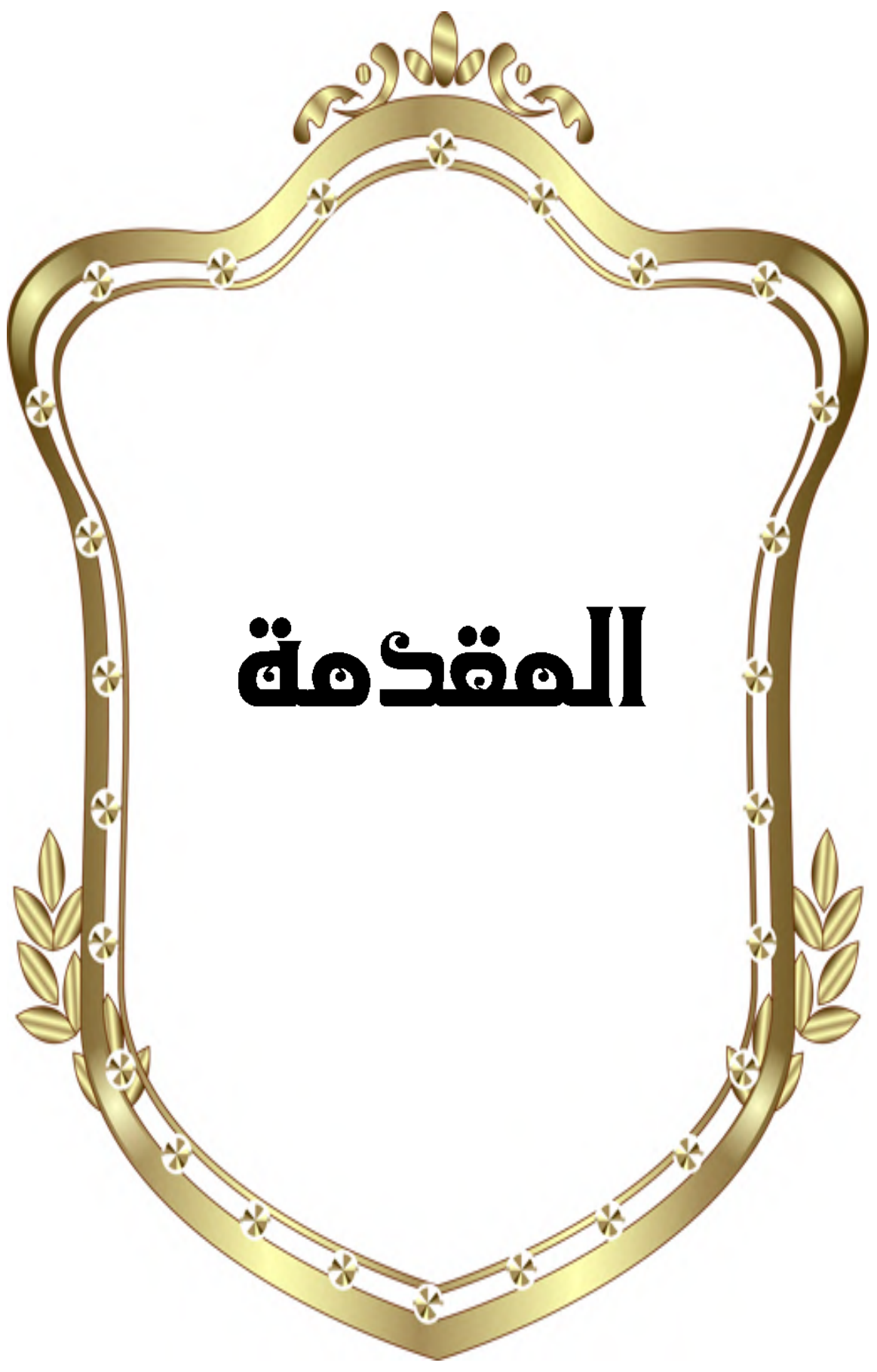





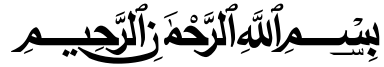

الحمد الله الذي أنزل على عبده الكتاب ولم يجعل لـه عوجاً، والصلاة

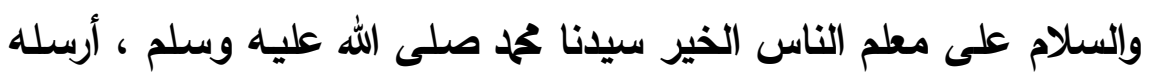
ربه بالهدى ودين الدق ليظهره على الدين كله وعلى آله وصحبه مصابيح الهاى ومن تبعهم بإحسان إلى يوم الدين .

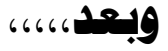

فإن مجلة قطاع أصول الدين تزف إلى قرائها في العالم والباحثين

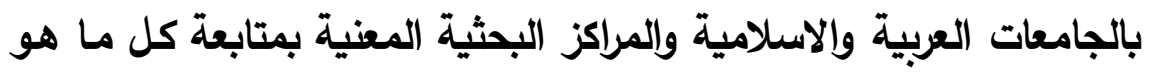

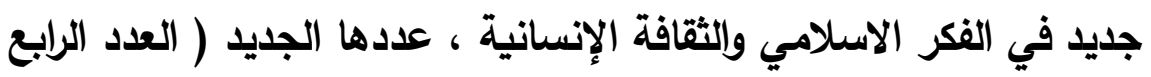

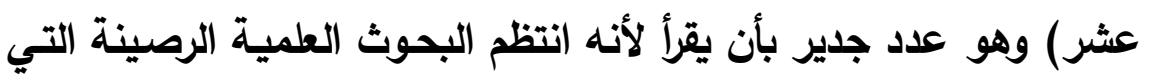

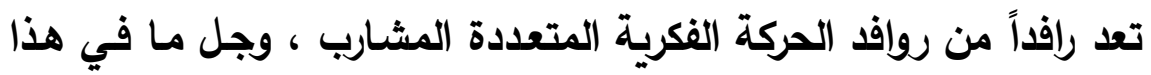

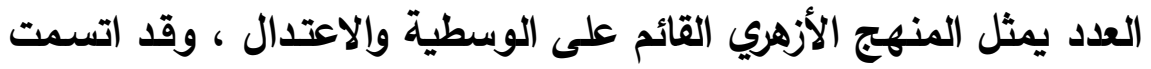

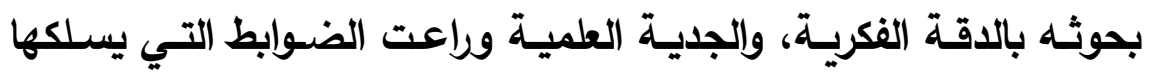

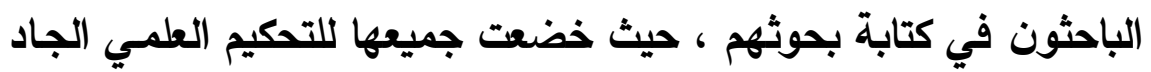

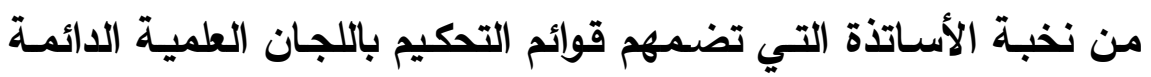

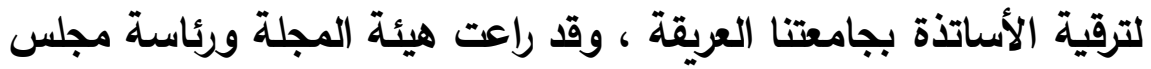

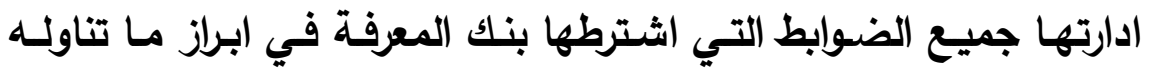

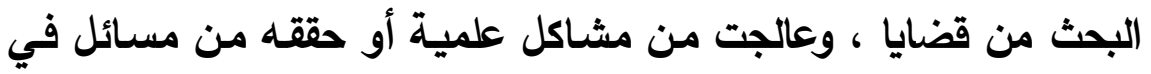
ملخص كتبه صاحبه باللغة العربية ثم دفع بـه مجلس التحرير الـى مركز

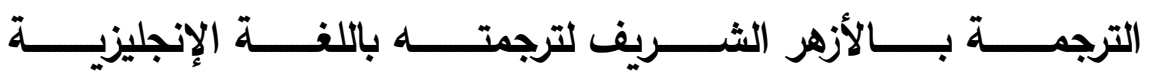
محتوياً على المعايير التي تتطلبها جودة (English - abstract) البحوث العالمية الصالحة للنشر على المواقع الدولية ومنها : 


\section{1 - (Title ) عنوان البحث

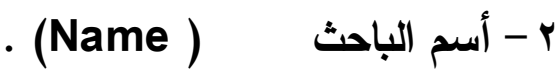

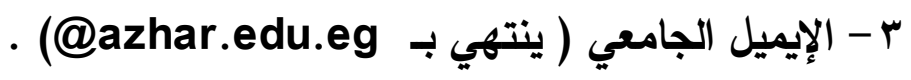

ـ - الكلمات المفتاحية للبحث ( Key words ) .

ه - التوصـيف الأكساديمي للباحـث (القســم، الكليــة والجامعــة)

- (Academic affiliation)

وإني على يقين باله أن من تشملهم تخصصات هذا القطاع العريق

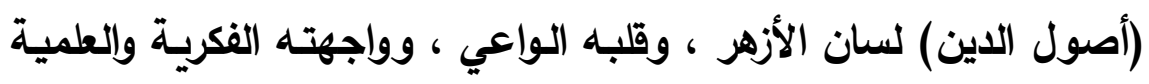

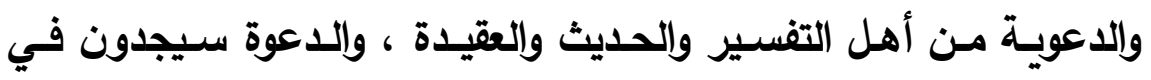

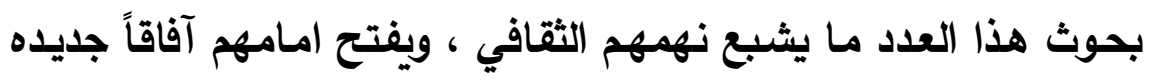

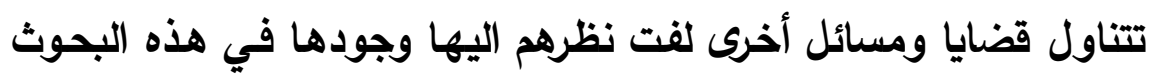

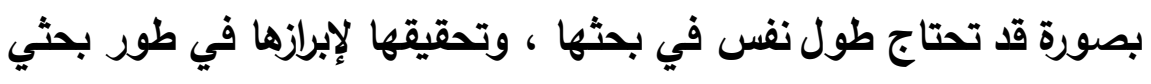

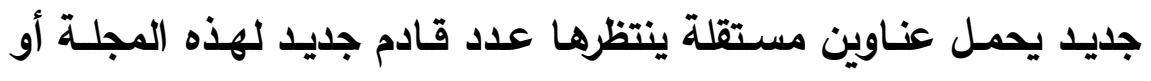

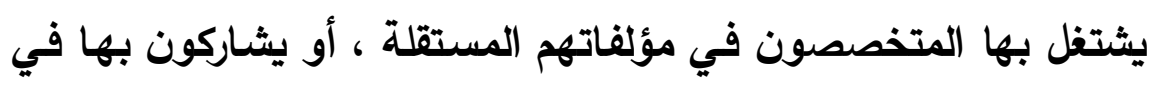
مؤتمرات علمية ومحافل دولية .

والله نسأل وهو خير مسؤول ، وأعظم مأمول أن يعم النفع بهذا العدد

طلاب المعرفة والباحثين عنها . والله من وراء القصد وهو الهادي إلى سواء السبيل .

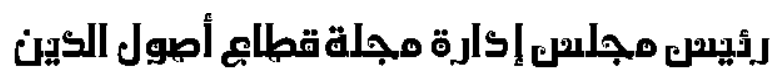

وعميذكلية أصول الذين

أ. ك/ عبذ الفتاجمعبد الفنيه العواري. 


\title{
AL-AZHAR JOURNAL
}

\section{Of}

\section{The origins of religion Scientific-Annual-Court}

\author{
Dean of the Faculty
}

Chairman

Dr. Abdul Fattah Abdul Ghani Al-Awari

Volume 14 



\section{Publishing rules and regulations}

Distinguished professors, distinguished scientists and fellow brothers are happy to receive your scientific research for publication in the yearbook, to take into account the following rules and regulations in the research submitted for publication:

1- The research should be original and innovative, objective, comprehensive and comprehensive, and does not conflict with Islamic values, after being presented to arbitrators according to the scientific rules.

2- The research should not have been published before or submitted for publication to another party, and should not be derived from research or academic letter obtained by the researcher, supervisor or participant in the discussion.

3- The research, which includes the islamic texts, takes into account the control of these texts, by documenting the Qur'anic verses, and graduating the hadiths of the Prophet's hadiths in the margins at the bottom of each page.

4- The research should not exceed (50) pages comprehensive cover and indexes, taking into account the following technical controls:

A- Paper Size A - The size of paper A4 leaves a margin of four sides at a distance of $2.5 \mathrm{~cm}$.

B- The titles should be in the 16 th.

C- To write the text of the search in the 14th. 
D- Footnotes in 12.

E- Use single spaces between lines.

5- The research is submitted to the committee competent to supervise the printing of the yearbook after the approval of the scientific unit and the section to which this researcher belongs to the faculty members of the faculty, while the research of professors from abroad is provided to the editorial board directly.

6. Tables, shapes, manuscript forms, illustrations, etc., respectively, are numbered according to their presence in the research manuscript, and are provided with titles, each referred to in the same sequence as in the manuscript, and presented with separate papers.

7- The scientific method of documenting research is followed as follows:

- The sources and references in the search board are referred to in sequential numbers placed in brackets to the top [sic: (1) (2) ] and detailed at the bottom of each page separately.

- Explanations and notes in the search board are referred to as a star (sic: *) or more.

- A list of sources and references is placed in alphabetical order, according to the name of fame followed by other information of the Book, topped by the Holy Quran, if it includes them, as follows:

- The Holy Quran. 
Books: (author's name, title of the book, the name of the investigator [if any], the publishing house, the publishing country, the number of the edition referred to as " $i$ " if any, the date [if any] otherwise referred to as "D.T.").

- Research in periodicals: (author's name, search title, magazine name, issuer, issue country, magazine number [if any], number, date, place of search in the magazine represented by pages).

8 - The researcher is obliged to make the modifications requested by the arbitrators on his research according to the reports sent to him and provide the magazine with a modified copy of the research.

Please note that:

- What is published in the yearbook of opinions that express the thinking of its owners, and does not represent the opinion or direction of the yearbook.

- Research sent to the Yearbook is not returned to its owners, whether published or not.

- Inform the owners of the incoming research to reach the supervisory committee.

- The order of acceptable research for publication in the yearbook is subject to technical considerations.

- The researcher bears the expenses of printing the research in full, and after publishing his research a copy of the number in which the research is more than (20) derived from it. 



\section{Board of Directors}

\section{AL-AZHAR JOURNAL Of}

\section{The origins of religion}

\section{Chairman}

Dr. Abdul Fattah Abdul Ghani Al-Awari

Dean of The Faculty of Religious Origins in Cairo 


\title{
Members of the Board of Directors
}

\author{
Dr. Mohammed Eid Malik
}

Dean of the Faculty of Religious Origins and Advocacy in Assiut

\section{Dr. Ahmed Ali Al-Awdra}

Dean of the Faculty of Religious Origins and Advocacy Of Tanta

\section{Dr. Saad Mohammed Mohammed Shalabi}

Dean of the Faculty of Religion and Advocacy in

Mansoura

Credit Abdul Sadiq Afi

Dean of the Faculty of Islamic Studies Girls - Cairo

\section{Dr. Sami Abdel Fattah Hilal}

Dean of the Faculty of the Holy Quran Tanta

\section{Dr. Jamal Farouk Jibril}

Dean of the Faculty of Islamic Da'wa in Cairo

\section{Dr. Taha AbdulKhaleq Abdulaziz}

Undersecretary of the Faculty of Religious Origins in Cairo for Graduate Studies

\section{Mr. Sherif Akl}

General Manager of the College Library and Editor-inChief of the Magazine 